\title{
西双版纳热带季节雨林的生物量及其分配特征
}

\author{
吕晓涛 ${ }^{2} 2$ 唐建维 ${ }^{*}$ 何有才 ${ }^{3}$ 段文贵 ${ }^{3}$ 宋军平 ${ }^{3}$ 许海龙 ${ }^{3}$ 朱胜忠 ${ }^{3}$ \\ （1 中国科学院西双版纳热带植物园，云南预腊 666303）（2 中国科学院研究生院 北京 100049） \\ (3 西双版纳国家级自然保护区管理局预腊管理所,云南预腊 666300)
}

摘 要 根据 3 块 $1 \mathrm{hm}^{2}$ 样地的调查资料 利用 123 株样木数据建立以胸径 $(D)$ 为单变量的生物量预测方程。采用 样木回归分析法 (乔木层、木质藤本)和样方收获法 (灌木层、草本层), 获取西双版纳热带季节雨林的生物量, 并分 析了其组成和分配特征。结果表明, 西双版纳热带季节雨林的总生物量为 $(423.908 \pm 109.702) \mathrm{Mg} \mathrm{hm}^{-2}$ (平均值 \pm 标准差 , $n=3)$ 其中活体植物生物量占 $95.28 \%$ 粗死木质残体占 $4.07 \%$ 地上调落物占 $0.64 \%$ 。在其层次分配方 面: 乔木层优势明显，占 $98.09 \% \pm 0.60 \%$; 其次为木质藤本，占 $0.83 \% \pm 0.31 \%$; 灌木层和草本层生物量均小于木质 藤本的生物量, 附生植物最低, 仅为 $0.06 \% \pm 0.03 \%$ 。总生物量的器官分配以茎所占比例最高, 达 $68.33 \%$ 根、枝、 叶的比例分别为 $18.91 \% 、 11.07 \%$ 和 $1.65 \%$ 。乔木层生物量的径级分配主要集中于中等径级和最大径级。大树 $(D>70 \mathrm{~cm})$ 具有较高的生物量, 占整个乔木层的 $43.67 \% \pm 12.67 \%$ 。树种分配方面, 生物量排序前 10 位的树种占 乔木层总生物量的 $63.43 \% \pm 4.09 \%$ ，生物量集中分配于少量优势树种。西双版纳热带季节雨林乔木层叶面积指 数为 $6.39 \pm 0.85$ 。西双版纳热带季节雨林乔木层的地上生物量位于世界热带湿润森林的中下范围。

关键词 生物量 生物量分配 回归模型 热带季节雨林 西双版纳

\section{BIOMASS AND ITS ALLOCATION IN TROPICAL SEASONAL RAIN FOREST IN XISHUANGBANNA, SOUTHWEST CHINA}

LÜ Xiao-Tao ${ }^{1,2}$, TANG Jian-Wei ${ }^{1 *}$, HE You-Cai ${ }^{3}$, DUAN Wen-Gui ${ }^{3}$, SONG Jun-Ping ${ }^{3}$, XU Hai-Long ${ }^{3}$, and ZHU Sheng-Zhong ${ }^{3}$

${ }^{I}$ Xishuangbanna Tropical Botanical Garden , Chinese Academy of Sciences , Mengla, Yunnan 666303 , China , ${ }^{2}$ Graduate University of Chinese Academy of Sciences, Beijing 100049 , China, and ${ }^{3}$ Mengla Institute of Conservation , Xishuangbanna Bureau of National Nature Reserve , Mengla , Yunnan 666300 , China

\begin{abstract}
Aims Changes in the biomass of tropical forests play an important role in the global carbon cycle , but the biomass of these forests has been poorly quantified. A strategy for regional biomass estimation should supplement previous surveys with new data. Accurate data are necessary for reducing the uncertainty in the carbon budget of tropical regions .
\end{abstract}

Methods Biomass and its allocation were estimated for the tropical seasonal rain forest in Xishuangbanna , southwest China. Regression models relating tree biomass to $D B H$ (diameter at breast height, $1.3 \mathrm{~m}$ ) were developed, and a power-law allometric relationship $W=a D^{b}$ was used to estimate the tree biomass, where $W$ is the biomass of a tree ( $\mathrm{kg}$ of leaves, branches, stems or roots) , $a$ and $b$ are constants and $D$ is the $D B H$ $(\mathrm{cm})$. Other biomass components were sampled in different quadrats in three $1 \mathrm{hm}^{2}$ permanent research plots : shrubs (ten $25 \mathrm{~m}^{2}$ quadrats), herbs (ten $4 \mathrm{~m}^{2}$ quadrats), dead wood (the whole plot), large fallen branches (twenty-five $25 \mathrm{~m}^{2}$ quadrats) and litterfall (twenty-five $1 \mathrm{~m}^{2}$ quadrats). This method was used for estimating above- and below-ground biomass of live and dead plants (trees, seedlings, shrubs, herbs, woody lianas, epiphytes, coarse woody debris and litterfall).

Important findings Total biomass for the three plots was $370.163,550.119$ and $351.442 \mathrm{Mg} \mathrm{hm}$, with an average of $(423.908 \pm 109.702) \mathrm{Mg} \mathrm{hm}^{-2}$ (95\% confidence interval). Living biomass made up $95.28 \%$ of the total biomass, with coarse woody debris and litterfall comprising the rest. Most living biomass $(98.09 \% \pm 0.60 \%)($ Mean $\pm S D, n=3)$ of the seasonal rain forest was concentrated in the tree layer. In the allocation of total biomass, stems accounted $68.33 \%$ and roots, branches and leaves made up $18.91 \%$, $11.07 \%$ and $1.65 \%$, respectively. The biomass allocation among different $D B H$ classes was concentrated in 
the middle and largest classes, with large trees $(D>70 \mathrm{~cm})$ accounting for $43.67 \% \pm 12.67 \%$. The most important ten species, in terms of biomass , made up $63.43 \%$ of the tree layer. Leaf area index $(L A I)$ of the tree layer for the three plots was $5.73,7.35$ and 6.08 , with an average of 6.39 . Estimated aboveground biomass in our study sites fell within the range of published values for tropical moist forests and was lower than that of Malaysian and Cameroon rain forests, but higher than some neotropical rain forests. In terms of total biomass , Xishuangbanna tropical seasonal rain forest is also higher than moist forest in Brazil.

Key words biomass, biomass allocation, regression models, tropical seasonal rain forest, Xishuangbanna

目前, 大气中 $\mathrm{CO}_{2}$ 的急剧增加及其对全球气候 和环境的影响已成为一个世界广泛关注的问题 (Brown et al. , 1989)。热带森林是全球重要的碳 库, 其碳储存量占世界上植被总体碳库的 $37 \%$,在 全球碳循环中发挥着重要的作用 (Dixon et al. , 1994 ;Phillips \& Gentry, 1994)。鉴于此, 各国的科学 家针对热带森林开展了广泛的实验研究 (Malhi et $a l$. 1999) , 并在热带森林的碳储量和碳通量研究方 面取得了重要的进展 (Malhi et al.,1998;Gurney et $a l$. 2002)。但到目前为止, 对于原始热带森林究竟 是”碳汇”还是”碳源”及其对未来气候变化的响应等 问题尚无定论 (Körner, 1998; Chave et al.,2003)。土 地利用的变化以热带森林地区最为严重, 由此所导 致的热带地区向大气中的碳排量仍然是一个很不确 定的数字(Schimel ,1995), 而造成此不确定性的最主 要原因就在于对热带森林生物量的估算 (Keller et $a l$. 2001)。因此, 获得更为准确的热带森林生物量 数据成为进一步了解热带森林在全球碳循环中作用 的关键(Brown et al. 1989)。

生物量不仅能够反映生态系统在特定时段内积 累有机物质的能力, 而且是描述生态系统特征的重 要参数 (Overman et al. 1994)。自 20 世纪 60 年代以 来, 尤其是国际生物学计划 (IBP) 开展后, 世界各国 的科学家们对全球各生物区域的森林群落的生物量 和生产力进行了广泛的研究, 总结分析了热带地区 不同森林类型的生物量及其在各器官中的分配规律 (唐建维等，2003）对各种生物量模型尤其是地上生 物量的模型进行了比较和评价, 同时将热带森林的 生物量与全球大气中的 $\mathrm{CO}_{2}$ 含量、温室效应等有机 地结合起来进行了深入探讨。但相对于温带地区森 林的研究状况而言, 热带不同地区之间的森林群落 生物量的比较研究及其时间变化的研究仍然相当匮 乏(Chave et al. 2001)。

位于云南省南部的西双版纳 $\left(21^{\circ} 09^{\prime} \sim 22^{\circ} 33^{\prime} \mathrm{N}\right.$, $\left.99^{\circ} 58^{\prime} \sim 101^{\circ} 50^{\prime} \mathrm{E}\right)$ 拥有我国最大面积的热带雨林。
自 20 世纪 60 年代以来, 许多学者从群落结构、群落 学特征以及树种多样性方面对西双版纳的热带雨林 进行了研究, 发表了大量论文 (Cao et al. 1996; 吴邦 兴, 1992 朱华等,1998)。虽然部分学者曾对季节雨 林的生物量进行了研究(党承林等, 1997;江志立等, 1998 ; 郑征等,2000) ,但存在着诸如样方单一、面积 较小、生物量组分测定不全面等不足。为了较全面 地了解西双版纳热带季节雨林生物量的组成及其空 间分配特征，我们于 2004 年 12 月至 2005 年 2 月在 西双版纳的不同地点建立了 3 块 $1 \mathrm{hm}^{2}$ 热带季节雨 林固定样地。根据群落调查资料, 运用相对生长法, 建立幂函数方程 $\left(W=a D^{b}\right)$ 以估算季节雨林的生物 量, 并分析了其组分、层次、径级及种类分配状况，以 期为在本地区进一步开展碳储量和碳循环研究提供 基础数据。

\section{1 自然背景}

研究地点位于西双版纳傣族自治州预腊县境 内，所建立的 3 块样地均在西双版纳国家级自然保 护区内, 其中 1 号样地(Plot I) 位于预仑片段内 2 号 样地 (Plot II) 和 3 号样地 (Plot III) 位于预腊片段内。 该地区属于西南热带季风气候,干、湿季变化明显， 一年可分为干热、湿热和雾凉 3 季, $3 \sim 5$ 月为干热 季, 气温较高, 雨量较少; $6 \sim 10$ 月为雨季 (湿热季), 气候湿热，此时期集中了全年降水的 $85 \% ; 11$ 月至 次年 2 月为雾凉季, 降雨较少, 但早晚有浓雾, 空气 湿度较大, 可以弥补此时期降雨量的不足。年均温 为 $21.4{ }^{\circ} \mathrm{C}$, 年均降雨量达 $1539 \mathrm{~mm}$ 。土壤类型为砖 红壤, 母岩为白严系砂岩, $\mathrm{pH}$ 值在 5.0 以下 (表 1)。

3 块样地的植被为西双版纳典型的地带性植 被均是以线毛番龙眼 (Pometia tomentosa) 、千果榄 仁 (Terminnalia myriocarpa ) 为标志的热带季节雨林, 该群系是西双版纳最具代表性的沟谷雨林类型, 具 有最高的物种多样性, 更接近于典型的湿热雨林(朱 华等,1998)。3块样地间的植物种类虽存在一定差 
表 1 西双版纳热带季节雨林样地基本特征

Table 1 Plot characteristics of tropical seasonal rain forest communities in Xishuangbanna

\begin{tabular}{|c|c|c|c|c|c|c|c|}
\hline 地点 & 样地号 & 纬度 & 经度 & 海拔 & 坡向 & 坡度 & 坡位 \\
\hline Study site & Plot No. & Latitude & Longitude & Altitude & Aspect & Slope & Position \\
\hline 秒仑 Menglun & I & $21^{\circ} 57^{\prime} \mathrm{N}$ & $101^{\circ} 12^{\prime} \mathrm{E}$ & $730 \mathrm{~m}$ & $\mathrm{NW}$ & $15^{\circ} \sim 20^{\circ}$ & 中 Middle \\
\hline 预腊 Mengla & II & $21^{\circ} 32^{\prime} \mathrm{N}$ & $101^{\circ} 33^{\prime} \mathrm{E}$ & $580 \mathrm{~m}$ & EN & $25^{\circ} \sim 30^{\circ}$ & 下 Lower \\
\hline 曼养 Manyang & III & $21^{\circ} 27^{\prime} \mathrm{N}$ & $101^{\circ} 36^{\prime} \mathrm{E}$ & $640 \mathrm{~m}$ & NE & $20^{\circ} \sim 25^{\circ}$ & 下 Lower \\
\hline
\end{tabular}

异, 但均以樟科、大戟科、桑科、楝科及茜草科的种类 为最多。3 块样地共有 386 种乔木, 分属于 193 属、 65 科，以无患子科、番荔枝科、大戟科、樟科、楝科的 树种占优势, 其中样地 I 中乔木 263 种, 分属于 149 属、53 科; 样地 II 中乔木 177 种, 分属于 125 属、 52 科 样地 III 中乔木 181 种, 分属于 103 属、49 科。其 群落结构复杂, 可分为乔木层、灌木层、草本层和层 间植物。而乔木层又可分为 3 个亚层: 乔木 I 层主 要由线毛番龙眼、千果榄仁、多花白头树 (Garuga floribunda var. gamblai) 和其它乔木树种组成, 高度 $35 \sim 40 \mathrm{~m}$, 盖度约 $15 \%$;乔木 II 层以梭果玉莈 ( Barringtonia macrostachya)、滇南榽杪 (Chisocheton siamensis)、大叶白颜树 (Gironniera subaequalis)、琼楠 (Beilschmeidia brachythyrsa) 等组成, 高度 $15 \sim 30 \mathrm{~m}$, 盖度约 30\% ;乔木 III 层树高 3～10 m , 主要由窄序 崖豆树 (Millettia laptobotrya)、小叶藤黄( Garcinia cowa)、核实(Drypetes indica)、云南肉豆莛 (Myristica yunnanensis)、蚁花 (Mezzettiopsis creaghii) 等优势种以及乔 木的小树组成,盖度约 $35 \%$; 灌木层主要由乔木的 幼树组成, 较常见的灌木种类有染木 (Saprosma ternatum)、包疮叶 (Measa indica)、锈毛杜茎山 (Measa permollis)、细腺蓦木 (Mycetia gracilis) 等, 高度 $1 \sim 3$ $\mathrm{m}$,盖度约 $25 \%$; 草本层主要由乔木的幼苗和蕨类植 物组成, 较常见的草本种类有楼梯草 (Elatostema parvum)、山壳骨 ( Pseudoranthemum malaccense)、莠竹 (Microstegium ciliatum) 等, 高度 $0.5 \mathrm{~m}$ 左右, 盖度约 $15 \%$ 。层间植物丰富，木质藤本以刺果藤 (Byttneria grandifolia)、云南风车子 (Combretum yunnanensis)、滇 南马钱 (Strychnos nitida)、奶子藤 (Bousigonia mekongensis) 为主; 附生植物主要有爬树龙 (Rhaphidophora decursiva)、粗茎崖角藤 (Rhaphidophora crassicaulis)、巢 偋( Neottopteris nidus) 等。

\section{2 研究方法}

\section{1 样地调查}

为方便调查 将每块 $1 \mathrm{hm}^{2}$ 样地划分为 100 个 10 $\mathrm{m} \times 10 \mathrm{~m}$ 的样方, 对样方内胸径 $(D) \geqslant 2.0 \mathrm{~cm}$ 的乔 木层个体以及木质藤本进行每木调查, 测量记录植 物名称、胸径、高度和冠幅等, 并挂牌标号, 同时将每 株个体的位置按照比例绘制在坐标图上。并记录每 株乔木上附生莎类的丛数以及附生藤本的株数、粗 度、长度。

\section{2 生物量获取}

\subsection{1 乔木层}

由于热带雨林中树木种类丰富且同种个体数量 较少, 不可能对每一树种都建立生物量模型 (Overman et al. ,1994) 样木的数量只能根据乔木不同径 级的个体数量来确定, 并采用收获法测定每株样木 的生物量。在野外将样木伐倒后 将树干钴断称重, 并在基部、胸径 $(1.3 \mathrm{~m})$ 处、树干中部和顶部各取一 个圆盘 将圆盘在野外称取鲜重; 对于野外不能直接 称重的粗大树干，分段测量并计算体积 取圆盘测其 体积(排水法)和干重, 计算密度 根据树干体积和密 度得其干重。根的生物量则采用全挖法, 并分为根 颈、根桩、大根 $(D \geqslant 2 \mathrm{~cm})$ 、小根 $(0.5 \mathrm{~cm} \leqslant D<2 \mathrm{~cm})$ 和细根 $(D<0.5 \mathrm{~cm})$ 等不同级别, 同时顺着根系, 仔 细地将细根全部挖出, 分别进行称重和取样; 另将新 枝和老枝、新叶和老叶分别称重。

由于热带雨林具有较高的树种多样性, 而且乔 木层植株的径级差别很大 $(2 \sim 207 \mathrm{~cm})$ 特将分属于 71 种、 54 属和 28 科的 123 株样木按胸径大小分为 小径级组 $(2 \mathrm{~cm} \leqslant D \leqslant 5 \mathrm{~cm}$ )、中径级组 $(5 \mathrm{~cm}<D \leqslant$ $20 \mathrm{~cm}$ ) 和大径级组 $(D \geqslant 20 \mathrm{~cm})$, 利用样木各器官 (干、枝、叶、根) 的干重和总干重建立各器官及总生 物量与样木胸径 $(D)$ 的幕回归方程 $\left(W=a D^{b}\right)$ 。根 据样地每木调查的结果及相应的回归方程计算乔木 层各个体的生物量, 并由此获得乔木层的总生物量。

\section{2 .2 灌木层和草本层}

在每一样地的左右两侧分别设立 5 个 $5 \mathrm{~m} \times 5$ $\mathrm{m}$ 的样方 (共 10 个), 对样方内的灌木层个体 ( $D<$ $2.0 \mathrm{~cm}, H>1 \mathrm{~m})$ 采用收获法测定各器官的生物量, 并以 10 个样方的平均值来推算样地中灌木层的总 
生物量。在每一个 $5 \mathrm{~m} \times 5 \mathrm{~m}$ 样方内设置一个 $2 \mathrm{~m} \times$ $2 \mathrm{~m}$ 小样方, 按同样方法获取草本层植株各器官的 生物量及总生物量。

\subsection{3 木质藤本}

在样地外伐取与样地内木质藤本种类相同的样 藤 $(2 \mathrm{~cm} \leqslant D \leqslant 14.5 \mathrm{~cm}$ ) 共 13 根, 测定其胸径和长 度, 分器官称重并取样。利用木质藤本胸径的平方 乘长度 $\left(D^{2} L\right)$ 与其生物量建立幂回归模型 $(W=$ $\left.a\left(D^{2} L\right)^{b}\right)$ 。依据样地内木质藤本的调查数据, 计算 全部木质藤本的生物量。

\section{2 .4 附生植物}

由于热带雨林中的附生植物非常丰富, 本研究 只对样地内附生于乔木上易于测定的一些种类如崖 角藤 (Rhaphidophora spp.)、爬树龙的茎粗度和长度 进行了估测, 同时对附生在乔木个体上的巢蕨丛数 进行了记录。在样地外分别选取有代表性的一定数 量的植株样本, 按收获法对茎、叶、根分别称重。

\subsection{5 地上调落物}

在样地的纵横两个方向上, 从样地左下角的样 方开始, 每隔 1 个 $10 \mathrm{~m} \times 10 \mathrm{~m}$ 样方设置 1 个 $1 \mathrm{~m}^{2}$ $(1 \mathrm{~m} \times 1 \mathrm{~m}$ )的样方 (乔木层样方的右下角)共 25 个 样方收集其内所有的地上凋落物, 包括枯落叶、小枝 (小头直径 $<2.0 \mathrm{~cm}$ )、花果、树皮等。在实验室中将 各组分进行分捡, 烘干后称重, 得到每一样方内的凋 落物量。以 25 个样方的平均值推算样地内的地上 调落物的生物量。

\subsection{6 粗死木质残体}

粗死木质残体包括枯立木 $(D \geqslant 2.0 \mathrm{~cm})$ 、倒木 和枯落大枝 (小头直径 $\geqslant 2.0 \mathrm{~cm}$ )。对样地内的枯立 木进行调查, 测量记录其胸径和树高。根据乔木生 物量回归方程得其生物量。同时调查样地内所有的 完整倒木, 采用乔木样木的取样和计算方法获得其 生物量。采用与地上凋落物调查同样的样方设置方 法, 对均匀分布于样地中的 25 个 $10 \mathrm{~m} \times 10 \mathrm{~m}$ 和 5 $\mathrm{m} \times 5 \mathrm{~m}$ 的样方内的倒木残体和枯落大枝进行收集 并称取鲜重。

在称取以上各组分鲜重后, 及时采集、称取各组 分的少量样品, 带回实验室内进行烘干处理, 茳、根、 枝的样品在 $105{ }^{\circ} \mathrm{C}$ 下, 叶和花果的样品在 $75{ }^{\circ} \mathrm{C}$ 下烘 干至恒重后称取干重。根据干鲜重之比计算各器官 (或组分)的重量。

\subsection{7 叶面积指数}

使用便携式叶面积仪 (LI-3000A) 测定样地内所 采集的不同树种的树叶叶面积，根据叶面积比重法
测定群落的叶面积指数。

\section{3 结果与分析}

\section{1 乔木层生物量回归模型}

大量森林群落生物量的研究表明:乔木生物量 与其胸径 $(D)$ 存在着很好的相关关系 (Araujo et al. , 1999 ;Brown 1997; Chave et al . 2001; Overman et al . , 1994)。由于热带森林树种多样, 树形特征差异极 大，而且对于大树的树高估计的误差常常高达 5 $10 \mathrm{~m}$, 因而在进行生物量估算时树高 $(H)$ 并不是一 个很好的参数 (Chave et al. ,2001)。为避免因树高 估测所带来的生物量估算误差, 在本研究中, 生物量 预测方程采用以树木胸径 $(D)$ 为单变量的非线性幂 指数方程 $\left(W=a D^{b}\right)$, 该方程能够较真实地反映树木 生物量 $(W)$ 随树木胸径 $(D)$ 的变化趋势 (Chave et al. 2001 温达志等,1999; 郑征等,2000)。乔木各 器官生物量和总生物量的幂指数回归模型见表 2 。 经统计学检验，各径级乔木干、枝、根和总生物量，以 及木质藤本生物量回归模型的相关系数均达到极显 著水平 $(p<0.001)$ 。

\section{2 乔木层的生物量及其分配}

根据 3 块 $1 \mathrm{hm}^{2}$ 样地的乔木调查数据, 由表 2 所 列乔木的生物量回归模型直接推算出 3 块样地的乔 木层生物量。其生物量分别为: $348.040 \mathrm{Mg} \mathrm{hm}-2$ (Plot I) ,516.724 Mg hm-2 (Plot II) 和 $325.037 \mathrm{Mg}$ $\mathrm{hm}^{-2}$ (Plot III) ,平均为 $396.587 \pm 104.664 \mathrm{Mg} \mathrm{hm}^{-2}$ (表 3)。

\subsection{1 器官分配}

乔木层各器官的生物量及其所占比例见表 3 , 其中树干的生物量最高, 为 $(272.70 \pm 76.12) \mathrm{Mg}$ $\mathrm{hm}^{-2}$, 占乔木层生物量的 $2 / 3$; 树根次之，约占 $1 / 5$; 枝约占 $1 / 10$ 树叶生物量最小。树干和树根约占据 了乔木层生物量的 $90 \%$ 。可见, 其乔木层各器官的 生物量分配呈如下趋势 树干 > 树根 > 树枝 > 树叶。 作为反映植物群落生产力高低重要指标的叶面积指 数 经测定 3 块样地的乔木层叶面积指数分别为 $5.73 、 7.35$ 和 6.08 ,平均为 $6.39 \pm 0.85$ 略低于海南 黎母山热带山地雨林乔木层的叶面积指数 (6.533) (黄全等,1991)。

\subsection{2 径级分配}

由表 4 可见, 3 块样地中 $D \geqslant 2 \mathrm{~cm}$ 的乔木层植 株个体的密度为 $1950 \sim 2450$ 株 $\mathrm{hm}^{-2}$, 以胸径 $D<$ $10 \mathrm{~cm}$ 的个体占绝对优势, 占乔木层植株数量的 $80 \%$ 左右, 但其生物量仅占乔木层总量的 $2.69 \%$ 。 
表 2 西双版纳热带季节雨林乔木和木质藤本生物量回归模型

Table 2 Regression models for biomass of tree and woody liana in tropical seasonal rain forest in Xishuangbanna

\begin{tabular}{|c|c|c|c|c|}
\hline $\begin{array}{l}\text { 生活型 } \\
\text { Life form }\end{array}$ & $\begin{array}{c}\text { 径级及样木数 } \\
D B H \text { classes and sample no. }\end{array}$ & $\begin{array}{l}\text { 器官 } \\
\text { Organ }\end{array}$ & $\begin{array}{c}\text { 回归模型 } \\
\text { Regression models }\end{array}$ & $\begin{array}{c}\text { 相关系数 } \\
\text { Regression coefficients }(r)\end{array}$ \\
\hline 乔木 & \multirow{5}{*}{$\begin{array}{l}2 \mathrm{~cm} \leqslant D \leqslant 5 \mathrm{~cm} \\
(N=46)\end{array}$} & 干 Stem & $W_{\mathrm{S}}=0.0733 D^{2.5884}$ & $0.8960^{* * *}$ \\
\hline Tree & & 枝 Branch & $W_{\mathrm{B}}=0.0135 D^{2.5158}$ & $0.7317^{* * *}$ \\
\hline & & 叶 Leaf & $W_{\mathrm{L}}=0.0394 D^{1.456}$ & $0.6675^{* * *}$ \\
\hline & & 根 Root & $W_{\mathrm{R}}=0.028 D^{2.399}$ & $0.8266^{* * *}$ \\
\hline & & 总 Total & $W_{\mathrm{T}}=0.1471 D^{2.4399}$ & $0.9076^{* * *}$ \\
\hline & \multirow{5}{*}{$\begin{array}{l}5 \mathrm{~cm}<D \leqslant 20 \mathrm{~cm} \\
(N=55)\end{array}$} & 干 Stem & $W_{\mathrm{S}}=0.1086 D^{2.3169}$ & $0.9453^{* * *}$ \\
\hline & & 枝 Branch & $W_{\mathrm{B}}=0.0186 D^{2.4685}$ & $0.8619^{* * *}$ \\
\hline & & 叶 Leaf & $W_{\mathrm{L}}=0.0455 D^{1.6636}$ & $0.7675^{* * *}$ \\
\hline & & 根 Root & $W_{\mathrm{R}}=0.0242 D^{2.4205}$ & $0.9357^{* * *}$ \\
\hline & & 总 Total & $W_{\mathrm{T}}=0.1815 D^{2.3222}$ & $0.9591^{* * *}$ \\
\hline & \multirow{5}{*}{$\begin{array}{l}D>20 \mathrm{~cm} \\
(N=22)\end{array}$} & 干 Stem & $W_{\mathrm{S}}=0.0401 D^{2.6752}$ & $0.9663^{* * *}$ \\
\hline & & 枝 Branch & $W_{\mathrm{B}}=0.0829 D^{2.0395}$ & $0.9136^{* * *}$ \\
\hline & & 叶 Leaf & $W_{\mathrm{L}}=0.0979 D^{1.3584}$ & $0.7976^{* * *}$ \\
\hline & & 根 Root & $W_{\mathrm{R}}=0.0111 D^{2.6801}$ & $0.9686^{* * *}$ \\
\hline & & 总 Total & $W_{\mathrm{T}}=0.0932 D^{2.5602}$ & $0.9681^{* * *}$ \\
\hline $\begin{array}{l}\text { 木质藤本 } \\
\text { Woody liana }\end{array}$ & $\begin{array}{l}2 \mathrm{~cm} \leqslant D \leqslant 14.5 \mathrm{~cm} \\
(N=13)\end{array}$ & 总 Total & $W_{\mathrm{T}}=0.0729\left(D^{2} L\right)^{0.8642}$ & $0.9423^{* * *}$ \\
\hline
\end{tabular}

随着径级的增加, 个体数量迅速减少, 而生物量则迅 速增大 , 并在中径级范围内达到一个峰值。样地 I 的峰值出现在 $70 \sim 80 \mathrm{~cm}$ 范围内, 占乔木层总量的 $16.67 \%$ 样地 II 的峰值出现在 $50 \sim 60 \mathrm{~cm}$ 范围内, 占该样地乔木层总量的 $10.55 \%$; 样地 III 中则是 $30 \sim 40 \mathrm{~cm}$, 其比例为 $14.14 \%$ 。此后, 随着径级的增 加, 生物量呈下降趋势, 但至最大一个径级时, 生物 量再次上升 到达另一个峰值。各样地中, 最大径级 的树木生物量所占比例都较高，对整个乔木层的贡 献较大。样地 II 和 III 中 最大径级树木的生物量所 占比例在各径级中最高, 分别达 $16.65 \%$ 和 $14.20 \%$ 样地 I 中虽然仅列各径级对生物量贡献的 第三位, 但也达到了 $9.85 \%$ 。生物量高峰值在中径 级和大径级出现, 这一规律与郑征等 (1999) 的研究 结果相同。

将乔木层按径级分为 3 个等级: 小径级等级 $(D \leqslant 20 \mathrm{~cm})$ 树木生物量所占百分比最小, 仅为 $8.01 \% \pm 1.93 \%$; 中径级等级范围 $(20 \mathrm{~cm}<D \leqslant 80$ $\mathrm{cm}$ ) 在各样地中所占比例最大, 为 $60.12 \% \pm$ $11.42 \%$; 而大径级等级 $(D>80 \mathrm{~cm})$ 则次之, 为 $31.87 \% \pm 13.34 \%$ 。可见西双版纳热带季节雨林的 生物量分配方式为中间高, 两头低, 该结果与冯志立 等(1998)的研究结果一致。但样地 II 有所不同, 大 径级等级 (46.24\%) 和中径级等级 ( $47.91 \%$ ) 所占的 比例基本相同, 差异并不明显。这也从另一方面说 明了 3 块样地上的森林群落在立木径级结构上的差
异。

\subsection{3 种类分配}

人们常常以生物多样性指数、重要值和生物量 等指标作为依据从不同的方面来评价森林群落或生 态系统的地位。多样性指数反映森林物种的丰富度 及均匀度, 重要值可反映某一种群在群落中的地位 和作用, 而生物量则能揭示种群的功能地位 (温达志 等,1999)。表 5 反映了西双版纳热带季节雨林中按 生物量排序前 10 位的树种的个体数量及其生物量 情况。在样地 I 和样地 II 中, 这 10 种树木的个体数 量仅占整个乔木层的 $10 \%$ 左右, 但是其生物量比例 却占 $65 \%$ 以上; 在样地 III 中, 个体数量比例稍大, 为 $22 \%$, 而生物量比例稍低，但也达到了 $59 \%$ 。可 见，在西双版纳热带季节雨林中 较少数量的优势树 种聚积了较高比例的生物量。其中生物量排序前 10 位的树种占乔木层总生物量的 $63.43 \% \pm$ $4.09 \%$ 。

在样地 I 和 II 中 ,上层树种(线毛番龙眼和千果 榄仁)的个体数量所占比例均不足 $3 \%$ ，但其生物量 分别占其乔木层生物量的 $34.95 \%$ 和 $35.57 \%$ ，充分 反映了上层树种的优势地位。在样地 III 中 没有千 果榄仁出现, 线毛番龙眼数量也较少, 使得梭果玉 莎、红果憼臭木 (Dysoxylum binecteriferum)、浆果乌柏 (Sapium baccatum) 等其它树种在生物量累积方面占 有优势。在树种生物量排序中均列在前 10 位的 3 块 样地共有树种仅两种，即线毛番龙眼和多花白头树， 
表 3 热带季节雨林生物量的层次分配和器官分配

Table 3 Biomass $\left(\mathrm{Mg} \mathrm{hm}^{-2}\right)$ allocation among different layers and various plant organs in tropical seasonal rain forest

\begin{tabular}{|c|c|c|c|c|c|c|c|c|c|c|c|}
\hline \multirow{2}{*}{$\begin{array}{l}\text { 层次 } \\
\text { Layer }\end{array}$} & \multirow{2}{*}{$\begin{array}{c}\text { 样地 } \\
\text { Plot }\end{array}$} & \multicolumn{2}{|c|}{ 茎 Stem } & \multicolumn{2}{|c|}{ 枝 Branch } & \multicolumn{2}{|c|}{ 叶 Leaf } & \multicolumn{2}{|c|}{ 根 Root } & \multicolumn{2}{|c|}{ 总计 Total } \\
\hline & & $\begin{array}{l}\text { 生物量 } \\
\text { Biomass }\end{array}$ & $\%$ & $\begin{array}{l}\text { 生物量 } \\
\text { Biomass }\end{array}$ & $\%$ & $\begin{array}{l}\text { 生物量 } \\
\text { Biomass }\end{array}$ & $\%$ & $\begin{array}{l}\text { 生物量 } \\
\text { Biomass }\end{array}$ & $\%$ & $\begin{array}{l}\text { 生物量 } \\
\text { Biomass }\end{array}$ & $\%$ \\
\hline \multirow{4}{*}{$\begin{array}{l}\text { 乔木层 } \\
\text { Tree }\end{array}$} & I & 238.396 & 68.50 & 37.733 & 10.84 & 4.418 & 1.27 & 67.493 & 19.39 & 348.040 & 100 \\
\hline & II & 359.924 & 69.66 & 49.873 & 9.65 & 4.951 & 0.96 & 101.976 & 19.74 & 516.724 & 100 \\
\hline & III & 219.764 & 67.61 & 38.379 & 11.81 & 4.655 & 1.43 & 62.239 & 19.15 & 325.037 & 100 \\
\hline & $\begin{array}{c}\text { 平均 } \\
\text { Average }\end{array}$ & $\begin{array}{c}272.695 \\
(76.115)\end{array}$ & 68.76 & $\begin{array}{c}41.995 \\
(6.830)\end{array}$ & 10.59 & $\begin{array}{c}4.675 \\
(0.267)\end{array}$ & 1.18 & $\begin{array}{c}77.236 \\
(21.586)\end{array}$ & 19.47 & $\begin{array}{c}396.600 \\
(104.664)\end{array}$ & 100 \\
\hline \multirow{4}{*}{$\begin{array}{l}\text { 灌木层 } \\
\text { Shrub }\end{array}$} & I & 1.213 & 52.08 & 0.208 & 8.93 & 0.312 & 13.40 & 0.596 & 25.59 & 2.329 & 100 \\
\hline & II & 0.609 & 53.33 & 0.106 & 9.28 & 0.155 & 13.57 & 0.272 & 23.82 & 1.142 & 100 \\
\hline & III & 0.995 & 50.41 & 0.292 & 14.79 & 0.239 & 12.11 & 0.448 & 22.70 & 1.974 & 100 \\
\hline & $\begin{array}{c}\text { 平均 } \\
\text { Average }\end{array}$ & $\begin{array}{c}0.939 \\
(0.306)\end{array}$ & 51.73 & $\begin{array}{c}0.202 \\
(0.093)\end{array}$ & 11.13 & $\begin{array}{c}0.235 \\
(0.079)\end{array}$ & 12.97 & $\begin{array}{c}0.439 \\
(0.162)\end{array}$ & 24.17 & $\begin{array}{c}1.815 \\
(0.609)\end{array}$ & 100 \\
\hline \multirow{4}{*}{$\begin{array}{l}\text { 草本层 } \\
\text { Herb }\end{array}$} & I & 0.534 & 35.82 & - & - & 0.328 & 22.0 & 0.629 & 42.19 & 1.491 & 100 \\
\hline & II & 0.928 & 41.15 & - & - & 0.572 & 25.37 & 0.755 & 33.48 & 2.255 & 100 \\
\hline & III & 0.455 & 18.56 & - & - & 0.628 & 25.61 & 1.369 & 55.83 & 2.452 & 100 \\
\hline & $\begin{array}{c}\text { 平均 } \\
\text { Average }\end{array}$ & $\begin{array}{c}0.639 \\
(0.253)\end{array}$ & 30.93 & - & - & $\begin{array}{c}0.509 \\
(0.160)\end{array}$ & 24.65 & $\begin{array}{c}0.918 \\
(0.396)\end{array}$ & 44.42 & $\begin{array}{c}2.066 \\
(0.508)\end{array}$ & 100 \\
\hline \multirow{4}{*}{$\begin{array}{l}\text { 木质藤本 } \\
\text { Liana }\end{array}$} & I & 3.347 & 81.85 & - & - & 0.206 & 5.04 & 0.536 & 13.11 & 4.089 & 100 \\
\hline & II & 2.469 & 87.71 & - & - & 0.152 & 5.40 & 0.194 & 6.89 & 2.815 & 100 \\
\hline & III & 2.339 & 87.70 & - & - & 0.144 & 5.40 & 0.184 & 6.90 & 2.667 & 100 \\
\hline & $\begin{array}{c}\text { 平均 } \\
\text { Average }\end{array}$ & $\begin{array}{c}2.718 \\
(0.548)\end{array}$ & 85.21 & - & - & $\begin{array}{c}0.167 \\
(0.034)\end{array}$ & 5.25 & $\begin{array}{c}0.305 \\
(0.200)\end{array}$ & 9.55 & $\begin{array}{c}3.190 \\
(0.782)\end{array}$ & 100 \\
\hline \multirow{4}{*}{$\begin{array}{l}\text { 附生植物 } \\
\text { Epiphyte }\end{array}$} & I & 0.115 & 50.66 & - & - & 0.065 & 28.63 & 0.047 & 20.71 & 0.227 & 100 \\
\hline & II & 0.087 & 45.31 & - & - & 0.061 & 31.77 & 0.044 & 22.92 & 0.192 & 100 \\
\hline & III & 0.139 & 45.57 & - & - & 0.098 & 32.13 & 0.068 & 22.30 & 0.305 & 100 \\
\hline & $\begin{array}{c}\text { 平均 } \\
\text { Average }\end{array}$ & $\begin{array}{c}0.114 \\
(0.026)\end{array}$ & 47.10 & - & - & $\begin{array}{c}0.075 \\
(0.020)\end{array}$ & 30.94 & $\begin{array}{c}0.053 \\
(0.013)\end{array}$ & 21.96 & $\begin{array}{c}0.241 \\
(0.058)\end{array}$ & 100 \\
\hline \multirow{4}{*}{$\begin{array}{l}\text { 总计 } \\
\text { Total }\end{array}$} & I & 243.605 & 68.39 & 37.941 & 10.65 & 5.329 & 1.50 & 69.301 & 19.46 & 356.176 & 100 \\
\hline & II & 364.017 & 69.59 & 49.979 & 9.55 & 5.891 & 1.13 & 103.241 & 19.73 & 523.128 & 100 \\
\hline & III & 223.692 & 67.29 & 38.671 & 11.63 & 5.764 & 1.73 & 64.308 & 19.34 & 332.435 & 100 \\
\hline & $\begin{array}{c}\text { 平均 } \\
\text { Average }\end{array}$ & $\begin{array}{c}277.105 \\
(75.923)\end{array}$ & 68.61 & $\begin{array}{l}42.197 \\
(6.749)\end{array}$ & 10.45 & $\begin{array}{c}5.661 \\
(0.295)\end{array}$ & 1.40 & $\begin{array}{c}78.950 \\
(21.184)\end{array}$ & 19.55 & $\begin{array}{c}403.913 \\
(103.923)\end{array}$ & 100 \\
\hline
\end{tabular}

括号内数值为标准差 样本数为 3 Standard deviation $(S D)$ in parenthesis $(n=3)$

这也从一个侧面反映了季节雨林中树种的多样性以 及不同区域的森林群落在树种组成上的差异性。

\section{3 灌木层生物量及其分配}

灌木层的生物量为 $1.815 \pm 0.609 \mathrm{Mg} \mathrm{hm}^{-2}$ (表 3) 均以乔木幼树贡献为最大, 真正灌木树种较少。 器官分配比例为: 茎为最大, 占 $51.73 \%$;根次之, 为 $24.17 \%$;枝和叶之和仅占 $24.1 \%$ 。本研究中的灌 木层生物量低于冯志立等 (1998) 和郑征等 (2000) 的 研究结果, 主要原因是乔木层最小起测胸径的设置 不同, 本研究为 $2 \mathrm{~cm}$,而在他们的研究中为 $5 \mathrm{~cm}$ 。

\section{4 草本层生物量及其分配}

热带季节雨林的林分郁闭度较高，林下光照较 弱, 草本植物不仅种类少, 数量也稀少。草本层主要 是由乔木和灌木的幼苗以及蕨类植物所组成。3 块 样地草本层的生物量为 $2.066 \pm 0.508 \mathrm{Mg} \mathrm{hm}^{-2}$ (表
3) 草本层的器官分配比例因样地而异, 在蕨类较多 的样地(样地 III)，根的比例较高，达 $55.83 \%$,为茎 的 3 倍, 叶的 2 倍; 在乔、灌木幼苗较多的样地(样 地 II) 则以茎为主 根和叶次之。

\section{5 木质藤本的生物量及其分配}

在样地 I、II、 III 中,胸径 $2 \mathrm{~cm}$ 以上的木质藤本 的植株数量分别为 $208 、 135 、 112$ 株。木质藤本的生 物量为 $3.190 \pm 0.782 \mathrm{Mg} \mathrm{hm}^{-2}$ (表 3)。器官分配以 茎占绝对优势，占据总生物量的 $85 \%$ 以上根次之， 占 $9.55 \%$ 旪最少, 仅占 $6 \%$ 。藤本植物叶所占比例 较低, 可能是由于样藤伐取时因部分藤本已攀援至 林冠并攀附于几株乔木的树冠,未能将其叶收集完 全所致。

\section{6 附生植物的生物量及其分配}

本研究中,附生植物种类的生物量主要以粗茎 
表 4 西双版纳热带季节雨林乔木层植株个体数目及生物量的径级分布

Table 4 Distribution of No. of individuals ( No: $\mathrm{hm}^{-2}$ ) and biomass $\left(\mathrm{Mg} \mathrm{hm}^{-2}\right)$ among various $\mathrm{DBH}$ classes for tree layer in tropical seasonal rain forest of Xishuangbanna

\begin{tabular}{|c|c|c|c|c|c|c|c|c|}
\hline \multirow{2}{*}{$\begin{array}{c}\text { 径级 } \\
D B H \\
\text { classes } \\
(\mathrm{cm})\end{array}$} & \multicolumn{2}{|c|}{ 样地 I Plot I } & \multicolumn{2}{|c|}{ 样地 II Plot II } & \multicolumn{2}{|c|}{ 样地 III Plot III } & \multicolumn{2}{|c|}{ 平均 Average } \\
\hline & $\begin{array}{c}\text { 个体数 } \\
\text { No. of } \\
\text { individual }\end{array}$ & $\begin{array}{l}\text { 生物量 } \\
\text { Biomass }\end{array}$ & $\begin{array}{c}\text { 个体数 } \\
\text { No. of } \\
\text { individual }\end{array}$ & $\begin{array}{l}\text { 生物量 } \\
\text { Biomass }\end{array}$ & $\begin{array}{c}\text { 个体数 } \\
\text { No. of } \\
\text { individual }\end{array}$ & $\begin{array}{l}\text { 生物量 } \\
\text { Biomass }\end{array}$ & $\begin{array}{c}\text { 个体数 } \\
\text { No. of } \\
\text { individual }\end{array}$ & $\begin{array}{l}\text { 生物量 } \\
\text { Biomass }\end{array}$ \\
\hline $2 \sim 5$ & $1562(63.94)$ & $4.309(1.24)$ & $1127(57.9)$ & $3.131(0.61) 1$ & $163(58.50)$ & $2.87(0.88)$ & $284(60.43)$ & $3.44(0.87)$ \\
\hline $5 \sim 10$ & $488(19.98)$ & $8.156(2.34)$ & $396(20.36)$ & $7.03(1.36)$ & $359(18.06)$ & $6.433(1.98)$ & $414(19.50)$ & $7.21(1.82)$ \\
\hline $10 \sim 20$ & $205(8.39)$ & $17.424(5.01)$ & $218(11.21)$ & $20.106(3.89)$ & $227(11.42)$ & $21.876(6.73)$ & $217(10.20)$ & $19.802(4.99)$ \\
\hline $20 \sim 30$ & $91(3.72)$ & $30.528(8.77)$ & $88(4.52)$ & $29.610(5.73)$ & $117(5.86)$ & $38.342(11.80)$ & $99(4.64)$ & $32.827(8.28)$ \\
\hline $30 \sim 40$ & $42(1.72)$ & $33.579(9.65)$ & $39(2.01)$ & $33.092(6.40)$ & $63(3.17)$ & $45.950(14.14)$ & $48(2.26)$ & $37.540(9.47)$ \\
\hline $40 \sim 50$ & $19(0.78)$ & $28.736(8.26)$ & $25(1.29)$ & $37.919(7.34)$ & $26(1.31)$ & $39.124(12.04)$ & $23(1.10)$ & $35.260(8.89)$ \\
\hline $50 \sim 60$ & $11(0.45)$ & $29.943(8.60)$ & $21(1.08)$ & $54.518(10.55)$ & $13(0.65)$ & $33.561(10.32)$ & $15(0.71)$ & $39.341(9.92)$ \\
\hline $60 \sim 70$ & $8(0.33)$ & $34.726(9.98)$ & $12(0.62)$ & $46.067(8.92)$ & $10(0.50)$ & $39.137(12.04)$ & $10(0.47)$ & $39.977(10.08)$ \\
\hline $70 \sim 80$ & $10(0.41)$ & $58.002(16.67)$ & $8(0.41)$ & $46.334(8.97)$ & $6(0.30)$ & $33.126(10.19)$ & $8(0.38)$ & $45.821(11.55)$ \\
\hline $80 \sim 90$ & $2(0.08)$ & $14.816(4.26)$ & $2(0.10)$ & $18.199(3.52)$ & $1(0.05)$ & $7.109(2.19)$ & $1.7(0.08)$ & $13.375(3.37)$ \\
\hline $90 \sim 100$ & $2(0.08)$ & $20.394(5.86)$ & $2(0.10)$ & $22.243(4.30)$ & $1(0.05)$ & $11.355(3.49)$ & $1.7(0.08)$ & $17.997(4.54)$ \\
\hline $100 \sim 110$ & $1(0.04)$ & $15.459(4.44)$ & $3(0.15)$ & $39.114(7.57)$ & - & - & $1.3(0.06)$ & $18.191(4.59)$ \\
\hline $110 \sim 120$ & $1(0.04)$ & $17.688(5.08)$ & - & - & - & - & $0.3(0.02)$ & $5.896(1.49)$ \\
\hline $120 \sim 130$ & - & - & $2(0.10)$ & $44.305(8.57)$ & $2(0.10)$ & $46.155(14.20)$ & $1.3(0.06)$ & $30.153(7.60)$ \\
\hline $130 \sim 140$ & - & - & $1(0.05)$ & $29.068(5.62)$ & - & - & $0.3(0.02)$ & $9.676(2.44)$ \\
\hline$>140$ & $1(0.04)$ & $34.280(9.85)$ & $1(0.05)$ & $86.029(16.65)$ & - & - & $0.7(0.03)$ & $40.089(10.11)$ \\
\hline 总计 Total & $2443(100)$ & $348.040(100)$ & $1945(100)$ & $516.724(100)$ & $1988(100)$ & $325.037(100)$ & $2125(100)$ & $396.587(100)$ \\
\hline
\end{tabular}

括号内数值为百分比 Percent of total in parenthesis

崖角藤、爬树龙、巢藓等为主, 并未对所有的附生植 物的生物量进行收集。由表 3 可知, 3 块热带季节 雨林样地中附生植物的生物量为 $(0.241 \pm 0.058)$ $\mathrm{Mg} \mathrm{hm}^{-2}$,所占比例较小, 仅占总生物量的 $0.06 \%$ 。 器官分配以茎为主，约占 $45 \%$; 叶次之，约占 $32 \%$; 根的比例最小。

\section{7 地上调落物}

3 块样地地上调落物现存量为 $(2.727 \pm 0.466)$ $\mathrm{Mg} \mathrm{hm}^{-2}$ (表 6), 并存在调落物的现存量与样地生 物量呈正相关的趋势。在凋落物的组分分配方面, 以枯落叶和枯落枝占绝对优势, 二者分别占调落物 现存量的 $49.65 \%$ 和 $43.60 \%$; 花果和杂屑比例较 小, 两者不足 $7 \%$ 。在各组分中, 枯落叶的比例最 高 其次为枝, 杂屑量最小。

\section{8 粗死木质残体储量及组分分配}

粗死木质残体 (枯立木、倒木、枯落大枝) 是森林 生态系统的重要组成部分, 并发挥着重要作用(李凌 浩等, 1996)。3 块热带季节雨林样地中粗死木质残 体的储量达(17.268 \pm 6.481$) \mathrm{Mg} \mathrm{hm}^{-2}$ (表 7)。

可能由于受到群落年龄、种类组成、生境异质性 及干扰程度不同的影响, 各样地中的粗死木质残体 在储量及组分分配方面并不相同。由于几株胸径较 大的乔木植株倒伏, 使倒木在样地 II 中的储量较 大, 占 $60 \%$; 而样地 I、III 中均以枯立木占优势, 占
$50 \%$ 左右。样地 I 中, 大枝储量则高于倒木, 而其它 样地中大枝储量则为最低。就 3 块样地的平均水平 来看 组分分配以倒木为最高, 枯立木次之, 大枝最 低。

\section{9 总生物量组成及其分配}

群落的总生物量包括活体植物地上和地下生物 量、地上调落物及粗死木质残体的储量。3 块样地 的总生物量分别为: $370.163 、 550.119 、 351.442 \mathrm{Mg}$ $\mathrm{hm}^{-2}$, 平均为 $(423.908 \pm 109.702) \mathrm{Mg} \mathrm{h}{ }^{-2}$ 。其中， 活体植物的贡献达 $95.28 \%$, 粗死木质残体和地上 调落物的总量占 $4.72 \%$ 。在层次分配中, 以乔木层 占绝对优势，所占比例为 $98.09 \% \pm 0.60 \%$; 木质藤 本次之, 为 $0.83 \% \pm 0.31 \%$; 比例最小的为附生植 物, 仅占 $0.06 \% \pm 0.03 \%$ 。灌木层和草本层生物量 均低于木质藤本植物的生物量。在样地 I 中, 灌木 层生物量略高于草本层, 在样地 II、 III 中则相反。 在活体植物生物量的器官分配方面 (表 8), 以茎为 最高，达 $68.61 \%$; 根次之，占 $19.55 \%$; 叶的比例最 小, 仅为 $1.40 \%$ 。其分配比例的顺序为: 茎 > 根 > 枝 $>$ 叶。综合活体植物、调落物及粗死木质残体的 数据, 各器官分配比例见表 8 。与活体植物的器官 分配比例相比, 茎和根的比例略有下降, 枝与叶略有 上升, 而分配比例的顺序与活体植物的器官分配顺 序相同。 
表 5 西双版纳热带季节雨林中主要树种的个体密度与生物量

Table 5 Individual density and biomass allocation of the main ten species in the tropical seasonal rain forest of Xishuangbanna

\begin{tabular}{|c|c|c|c|c|c|}
\hline \multirow[b]{2}{*}{$\begin{array}{l}\text { 样地 } \\
\text { Plot }\end{array}$} & \multirow[b]{2}{*}{$\begin{array}{l}\text { 树种 } \\
\text { Species }\end{array}$} & \multicolumn{2}{|c|}{ 植株个体 Individuals } & \multicolumn{2}{|c|}{ 生物量 Biomass } \\
\hline & & $\begin{array}{c}\text { 个体密度 } \\
\text { Density }\left(\text { No: }: \mathrm{hm}^{-2}\right)\end{array}$ & $\begin{array}{c}\text { 占乔木层\% } \\
\% \text { of the tree layer }\end{array}$ & $\mathrm{Mg} \mathrm{hm}-2$ & $\begin{array}{c}\text { 占乔木层\% } \\
\% \text { of the tree layer }\end{array}$ \\
\hline \multirow[t]{11}{*}{ I } & 线毛番龙眼 Pometia tomentosa & 70 & 2.87 & 87.355 & 25.10 \\
\hline & 千果榄仁 Terminalia myriocarpa & 1 & 0.04 & 34.280 & 9.85 \\
\hline & 梭果玉荵 Barringtonia macrostachya & 90 & 3.68 & 20.307 & 5.83 \\
\hline & 毛麻楝 Chukrasia tabularia var. velutina & 10 & 0.41 & 17.711 & 5.09 \\
\hline & 景洪猴欢喜 Sloanea cheliensis & 11 & 0.45 & 13.278 & 3.81 \\
\hline & 滇印杜英 Elaeocarpus varunua & 7 & 0.28 & 13.186 & 3.79 \\
\hline & 多花白头树 Garuga floribunda var. gamblai & 9 & 0.37 & 12.899 & 3.71 \\
\hline & 预仑翅子树 Pterospermum menglunense & 20 & 0.82 & 9.943 & 2.86 \\
\hline & 思茅栲 Castanopsis ferox & 3 & 0.12 & 9.671 & 2.78 \\
\hline & 白颜树 Gironniera subaequalis & 61 & 2.50 & 8.452 & 2.43 \\
\hline & 总计 Total & 282 & 11.54 & 227.084 & 65.25 \\
\hline \multirow[t]{11}{*}{ II } & 千果榄仁 Terminalia myriocarpa & 6 & 0.31 & 154.254 & 29.85 \\
\hline & 线毛番龙眼 Pometia tomentosa & 42 & 2.16 & 29.540 & 5.72 \\
\hline & 皮孔葱臭木 Dysoxylum lenticellatum & 31 & 1.59 & 27.229 & 5.27 \\
\hline & 团花树 Anthocephalus chinensis & 40 & 2.06 & 24.997 & 4.84 \\
\hline & 多花白头树 Garuga floribunda var. gamblai & 17 & 0.87 & 23.301 & 4.51 \\
\hline & 龙果 Pouteria grandiflora & 21 & 1.08 & 22.032 & 4.26 \\
\hline & 黄棉木 Metadina trichotoma & 8 & 0.41 & 19.395 & 3.75 \\
\hline & 盆架树 Winchia calophylla & 3 & 0.15 & 14.687 & 2.84 \\
\hline & 琴叶风吹楠 Horsfieldia pandurifolia & 22 & 1.13 & 13.900 & 2.69 \\
\hline & 长叶榆 Ulmus lanceaefolia & 7 & 0.36 & 13.260 & 2.57 \\
\hline & 总计 Total & 197 & 10.13 & 342.595 & 66.30 \\
\hline \multirow[t]{11}{*}{ III } & 梭果玉莈 Barringtonia macrostachya & 166 & 8.35 & 44.555 & 13.71 \\
\hline & 红果葱臭木 Dysoxylum binecteriferum & 17 & 0.86 & 25.898 & 7.97 \\
\hline & 浆果乌柏 Sapium baccatum & 1 & 0.05 & 24.686 & 7.59 \\
\hline & 粗壮琼楠 Beilschmiedia robusta & 1 & 0.05 & 21.469 & 6.61 \\
\hline & 白颜树 Gironniera subaequalis & 63 & 3.17 & 17.693 & 5.44 \\
\hline & 云南肉豆冦 Myristica yunnanensis & 165 & 8.30 & 13.720 & 4.22 \\
\hline & 线毛番龙眼 Pometia tomentosa & 8 & 0.40 & 13.521 & 4.16 \\
\hline & 多花白头树 Garuga floribunda var. gamblai & 1 & 0.05 & 11.355 & 3.49 \\
\hline & 云南黄杞 Engelhardtia spicata & 4 & 0.20 & 10.199 & 3.14 \\
\hline & 泰国黄叶树 Xanthophyllum siamensis & 12 & 0.60 & 7.865 & 2.42 \\
\hline & 总计 Total & 438 & 22.03 & 190.961 & 58.75 \\
\hline
\end{tabular}

表 6 西双版纳热带季节雨林地上调落物生物量

Table 6 Biomass $\left(\mathrm{Mg} \mathrm{hm}^{-2}\right)$ of litterfall in tropical seasonal rain forest of Xishuangbanna

\begin{tabular}{|c|c|c|c|c|c|c|c|c|c|c|}
\hline \multirow{2}{*}{$\begin{array}{l}\text { 样地 } \\
\text { Plot }\end{array}$} & \multicolumn{2}{|c|}{ 叶 Leaf } & \multicolumn{2}{|c|}{ 枝 Twig } & \multicolumn{2}{|c|}{ 花果 Fruit } & \multicolumn{2}{|c|}{ 杂屑 Other } & \multicolumn{2}{|c|}{ 总计 Total } \\
\hline & 生物量 Biomass & $\%$ & 生物量 Biomass & $\%$ & 生物量 Biomass & $\%$ & 生物量 Biomass & $\%$ & 生物量 Biomass & $\%$ \\
\hline I & 1.848 & 62.39 & 0.809 & 27.31 & 0.284 & 9.59 & 0.020 & 0.68 & 2.962 & 100 \\
\hline II & 1.103 & 36.41 & 1.819 & 60.05 & 0.072 & 2.38 & 0.035 & 1.16 & 3.028 & 100 \\
\hline III & 1.110 & 50.68 & 0.938 & 42.83 & 0.113 & 5.16 & 0.029 & 1.32 & 2.190 & 100 \\
\hline $\begin{array}{c}\text { 平均 } \\
\text { Average }\end{array}$ & $\begin{array}{c}1.354 \\
(0.428)\end{array}$ & 49.65 & $\begin{array}{c}1.189 \\
(0.550)\end{array}$ & 43.60 & $\begin{array}{c}0.156 \\
(0.112)\end{array}$ & 5.72 & $\begin{array}{c}0.028 \\
(0.007)\end{array}$ & 1.03 & $\begin{array}{c}2.727 \\
(0.466)\end{array}$ & 100 \\
\hline
\end{tabular}

括号内数值为标准差 样本数为 3 Standard deviation $(S D)$ in parenthesis $(n=3)$

\section{4 讨 论}

\section{1 西双版纳热带季节雨林生物量与其它热带森} 林的比较
朱华和蔡琳 (2005) 通过群落结构、生态外貌特 征、单位面积种多样性、个体/种数关系及树种的径 级分布等方面对云南的热带雨林和赤道低地热带雨 林进行了比较, 认为二者在以上各方面是几乎一样 
表 7 西双版纳热带季节雨林粗死木质残体储量及分配

Table 7 Biomass $\left(\mathrm{Mg} \mathrm{hm}^{-2}\right)$ of coarse woody debris and its allocation in tropical seasonal rain forest of Xishuangbanna

\begin{tabular}{|c|c|c|c|c|c|c|c|c|}
\hline \multirow{2}{*}{$\begin{array}{c}\text { 样地 } \\
\text { Plot }\end{array}$} & \multicolumn{2}{|c|}{$\begin{array}{c}\text { 枯立木 } \\
\text { Standing dead trees }\end{array}$} & \multicolumn{2}{|c|}{$\begin{array}{c}\text { 倒木 } \\
\text { Fallen dead trees }\end{array}$} & \multicolumn{2}{|c|}{$\begin{array}{c}\text { 大枝 } \\
\text { Large dead branches }\end{array}$} & \multicolumn{2}{|c|}{$\begin{array}{l}\text { 总计 } \\
\text { Total }\end{array}$} \\
\hline & 生物量 Biomass & $\%$ & 生物量 Biomass & $\%$ & 生物量 Biomass & $\%$ & 生物量 Biomass & $\%$ \\
\hline I & 5.548 & 50.32 & 2.148 & 19.48 & 3.329 & 30.20 & 11.025 & 100 \\
\hline II & 5.222 & 21.79 & 14.143 & 59.02 & 4.598 & 19.19 & 23.963 & 100 \\
\hline III & 8.128 & 48.33 & 6.050 & 35.98 & 2.638 & 15.69 & 16.817 & 100 \\
\hline $\begin{array}{c}\text { 平均 } \\
\text { Average }\end{array}$ & $\begin{array}{c}6.299 \\
(1.592)\end{array}$ & 36.48 & $\begin{array}{c}7.447 \\
(6.118)\end{array}$ & 43.13 & $\begin{array}{c}3.522 \\
(0.994)\end{array}$ & 20.40 & $\begin{array}{c}17.268 \\
(6.481)\end{array}$ & 100 \\
\hline
\end{tabular}

括号内数值为标准差 样本数为 3 Standard deviation $(S D)$ in parenthesis $(n=3)$

表 8 西双版纳热带季节雨林总生物量组成

Table 8 Mean value of total biomass $\left(\mathrm{Mg} \mathrm{hm}^{-2}\right)$ in the tropical seasonal rain forest of Xishuangbanna

\begin{tabular}{|c|c|c|c|c|c|c|c|c|c|c|}
\hline \multirow{2}{*}{$\begin{array}{c}\text { 生物量组分 } \\
\text { Component }\end{array}$} & \multicolumn{2}{|c|}{ 茎 Stem } & \multicolumn{2}{|c|}{ 枝 Branch } & \multicolumn{2}{|c|}{ 叶 Leaf } & \multicolumn{2}{|c|}{ 根 Root } & \multicolumn{2}{|c|}{ 总计 Total } \\
\hline & $\begin{array}{l}\text { 生物量 } \\
\text { Biomass }\end{array}$ & $\%$ & $\begin{array}{l}\text { 生物量 } \\
\text { Biomass }\end{array}$ & $\%$ & $\begin{array}{l}\text { 生物量 } \\
\text { Biomass }\end{array}$ & $\%$ & $\begin{array}{l}\text { 生物量 } \\
\text { Biomass }\end{array}$ & $\%$ & $\begin{array}{l}\text { 生物量 } \\
\text { Biomass }\end{array}$ & $\%$ \\
\hline $\begin{array}{l}\text { 活体生物量 } \\
\text { Living biomass }\end{array}$ & $\begin{array}{l}277.105 \\
(75.923)\end{array}$ & 68.61 & $\begin{array}{l}42.197 \\
(6.749)\end{array}$ & 10.45 & $\begin{array}{c}5.661 \\
(0.295)\end{array}$ & 1.40 & $\begin{array}{c}78.950 \\
(21.184)\end{array}$ & 19.55 & $\begin{array}{c}403.913 \\
(103.923)\end{array}$ & 100 \\
\hline $\begin{array}{l}\text { 凋落物 } \\
\text { Litterfall }\end{array}$ & - & - & $\begin{array}{c}1.189 \\
(0.550)\end{array}$ & 49.83 & $\begin{array}{c}1.354 \\
(0.428)\end{array}$ & 43.40 & - & - & $\begin{array}{l}2.727^{*} \\
(0.466)\end{array}$ & 100 \\
\hline $\begin{array}{l}\text { 粗死木质残体 } \\
\text { CWD }\end{array}$ & $\begin{array}{l}12.547 \\
(5.855)\end{array}$ & 72.66 & $\begin{array}{c}3.522 \\
(0.994)\end{array}$ & 20.39 & - & - & $\begin{array}{c}1.199 \\
(0.345)\end{array}$ & 6.94 & $\begin{array}{l}17.268 \\
(6.481)\end{array}$ & 100 \\
\hline $\begin{array}{l}\text { 总计 } \\
\text { Total }\end{array}$ & 289.652 & 68.33 & 46.908 & 11.07 & 7.015 & 1.65 & 80.149 & 18.91 & 423.908 & 100 \\
\hline
\end{tabular}

* : 包括枯落花果及杂屑 Fallen fruits, flowers and undistinguishable things included 括号内数值为标准差 样本数为 3 Standard deviation $(S D)$ in parenthesis $(n=3) \quad$ CWD : Coarse woody debris

表 9 西双版纳热带雨林生物量与其它森林群落的比较

Table 9 Comparison of biomass $\left(\mathrm{Mg} \mathrm{hm}^{-2}\right)$ between rain forest in Xishuangbanna and the other forest communities

\begin{tabular}{|c|c|c|c|c|c|c|c|}
\hline $\begin{array}{l}\text { 森林类型 } \\
\text { Forest type }\end{array}$ & $\begin{array}{c}\text { 地点 } \\
\text { Location }\end{array}$ & $\begin{array}{l}\text { 面积 } \\
\text { Area } \\
\text { of plot } \\
\left(\mathrm{hm}^{2}\right)\end{array}$ & $\begin{array}{c}\text { 最小胸径 } \\
\text { Minimum } \\
D B H \\
(\mathrm{~cm})\end{array}$ & $\begin{array}{c}\text { 乔木层地 } \\
\text { 上生物量 } \\
A G B \text { of } \\
\text { tree layer }\end{array}$ & $\begin{array}{c}\text { 乔木层 } \\
\text { 生物量 } \\
T B \text { of } \\
\text { tree layer }\end{array}$ & $\begin{array}{c}\text { 总生 } \\
\text { 物量 } \\
T B \\
T B\end{array}$ & $\begin{array}{c}\text { 引用文献 } \\
\text { References cited }\end{array}$ \\
\hline 低地湿性雨林 LWR & 圭亚那 Guiana & 22 & 10 & 309 & - & - & Chave et al. 2001 \\
\hline 低地湿润雨林 LMR & 巴拿马 Panama & 50 & 1 & 281 & - & - & Chave et al. 2003 \\
\hline 热带雨林 TRF & 巴西 Brazil & 392 & - & 264 & - & 372 & Keller et al. ,2001 \\
\hline 热带湿润雨林 TMF & 喀麦隆 Cameroon & 10 & 15 & 312 & - & - & Brown et al. 1989 \\
\hline 热带湿润雨林 TMF & 斯里兰卡 Sri Lanka & 8 & 10 & 205 & - & - & \\
\hline 热带湿润雨林 TMF & 马来西亚 Malaysia & 0.5 & 10 & 391 & - & - & \\
\hline 热带湿润雨林 TMF & 柬埔寨 Cambodia & - & 10 & 295 & - & - & Brown ,1997 \\
\hline 低地湿润雨林 LMR & 哥斯达黎加 Costa Rica & 0.3 & 1 & 234 & - & - & Dewalt \& Chave 2004 \\
\hline 山地雨林 TMRF & 海南 Hainan & 1 & 5 & 386 & 417 & 429 & $\begin{array}{l}\text { 李意德等 ,1998 } \\
\text { Li et al. , } 1998\end{array}$ \\
\hline 山地雨林 TMRF & 海南 Hainan & 0.15 & 5.5 & 492 & 572 & 588 & $\begin{array}{l}\text { 黄全等 ,1991 } \\
\text { Huang et al. , } 1991\end{array}$ \\
\hline 湿性季节雨林 WSRF & 西双版纳 Xishuangbanna & 0.25 & 5 & 536 & 683 & 693 & $\begin{array}{l}\text { 郑征等 } 2000 \\
\text { Zheng et al. , } 2000\end{array}$ \\
\hline 沟谷热带雨林 RTRF & 西双版纳 Xishuangbanna & 0.2 & 2 & 259 & 321 & 335 & $\begin{array}{l}\text { 党承林等 ,1997 } \\
\text { Dang et al. , } 1997\end{array}$ \\
\hline 湿性季节雨林 WSRF & 西双版纳 Xishuangbanna & 1 & 5 & 283 & 353 & 361 & $\begin{array}{l}\text { 冯志立等 ,1998 } \\
\text { Feng et al. , } 1998\end{array}$ \\
\hline 季节雨林 TSRF & 西双版纳 Xishuangbanna & 3 & 2 & 319 & 396 & 424 & 本研究 This study \\
\hline
\end{tabular}

LWR : Lowland wet rain forest TRF : Tropical rain forest TMF : Tropical moist forest LMR : Lowland moist forest TMRF : Tropical mountain rain forest WSRF : Tropical wet seasonal rain forest RTRF : Ravine tropical rain forest TSRF : Tropical seasonal rain forest $D B H$ : Diameter at breast height $A G B$ : Above-ground biomass $T B$ : Total biomass 
的, 云南热带雨林是真正的热带雨林类型，但是由于 海拔和纬度的影响, 使云南热带雨林又存在许多不 同于赤道低地雨林的特征。就生物量方面而言 (表 9) , 在相同径级测量标准下, 西双版纳热带季节雨林 的乔木层地上生物量 $\left(D \geqslant 2 \mathrm{~cm} 319 \mathrm{Mg} \mathrm{hm}^{-2} ; D \geqslant 5\right.$ $\left.\mathrm{cm}, 317 \mathrm{Mg} \mathrm{hm}{ }^{-2} ; D \geqslant 10 \mathrm{~cm}, 311 \mathrm{Mg} \mathrm{hm}^{-2}\right)$ 高于巴 西、哥斯达黎加、巴拿马、斯里兰卡的热带湿润雨林， 与柬埔寨和法属圭亚那的热带雨林相接近, 但低于 喀麦隆的热带雨林和马来西亚的龙脑香林 (Dipterocare forest），位于热带湿润森林地上生物量的中下范 围内 $\left(245 \sim 513 \mathrm{Mg} \mathrm{hm}^{-2}\right.$ ) (Brown \& Lugo , 1982)。虽 然西双版纳热带季节雨林发育在水分、热量和海拔 都达到极限的条件下 (朱华和蔡琳，2005)，但其总生 物量依然高于巴西的热带湿润雨林 (表 9)。与世界 上其它地区热带湿润雨林基本相当, 甚至略高于大 部分地区森林的生物量。

与国内其它热带地区的森林相比, 西双版纳热 带季节雨林总生物量 (407 $\mathrm{Mg} \mathrm{hm}^{-2}$ ) (为方便与其它 研究结果的比较, 该值未包含粗死木质残体的生物 量)要远低于黎母山热带山地雨林 (588 $\mathrm{Mg} \mathrm{hm}^{-2}$ ), 接近于尖峰岭的热带山地雨林 (429 $\left.\mathrm{Mg} \mathrm{hm}^{-2}\right)$ 。与 国内其它学者对西双版纳湿性和沟谷热带季节雨林 所做的研究相比, 本研究的结果远低于郑征等 (2000) 根据 $0.25 \mathrm{hm}^{2}$ 样地推算所得生物量 (693 Mg $\mathrm{hm}^{-2}$ ), 但高于党承林等 (1997)和冯志立等 (1998)的 结果 (表 9)。纵观所有关于西双版纳热带季节雨林 生物量的研究结果, 最高值 $\left(693 \mathrm{Mg} \mathrm{hm}^{-2}\right)$ 为最低值 $\left(335 \mathrm{Mg} \mathrm{hm}^{-2}\right)$ 的 2.1 倍。存在如此大差异可能有 以下几方面的原因: 一是样地面积有限且测量方面 存在误差。Brown 等(1995)将 $1 \mathrm{hm}^{2}$ 的样地划分为不 同面积等级 (125 5000 $\left.\mathrm{m}^{2}\right)$ 的小样方, 以研究不同 大小的样方面积对生物量估算误差的影响。结果表 明 样方面积越小, 不同样方之间的生物量误差越 大。因此仅仅依靠面积较小的样方所得的生物量数 值来推算群落的生物量一般会高于实际值 (Brown $e t$ $a l$. 1989)。同时树高测量方面所存在的误差也会 直接对生物量的预测产生影响。二是由于不同的样 地生长发育在不同的区域, 土壤理化性质及生境差 异较大,造成了森林群落生物量存在较大差异。 Laurance 等(1999)在南美热带雨林中的研究发现，土 壤的养分含量不仅显著影响森林的生物量及其对碳 的吸收和储存能力, 而且土壤的持水和排水性能与 生物量的空间差异也有极为密切的关系 (Chave et $a l$. 2001) ,同时森林中大树的存在量与土壤的排水
性能有较好的相关性 (Condit et al , 1995)。三是不 同地区的森林受干扰程度各异，对森林的生物量产 生影响。西双版纳季节雨林林下砂仁 (Amomum villosum) 的种植, 其抚育管理过程中林下乔木、灌木和 草本的清除管理方式对雨林生物量造成严重破坏， 乔木层、灌木层和木质藤本生物量分别降低 $53.73 \%$ 、94.72\% 和 $98.33 \%$, 而草本层生物量则增 加十几倍 (主要为砂仁) (郑征等,2001)。四是使用 不同的回归方程是产生生物量差异的又一原因 (Keller et al. 2001)。Araujo 等(1999)分析比较了针 对巴西地区热带雨林的 14 种生物量预测方程 结果 表明不同的方程预测结果差异较大, 最高值 (709 $\mathrm{Mg})$ 为最低值 $(161 \mathrm{Mg})$ 的 4.4 倍, 且 $80 \%$ 的预测结果 均不同程度的高于实测值。而在本研究中, 尽管使 用了同一生物量预测方程, 3块样地之间仍然存在 较大差异, 这可能是群落年龄的不同和生境的差异 所导致的群落结构、种类组成不同而造成的。如样 地 I中，小树较多而大径级树木相对较少, 样地 II 中 大径级树木最多, 而样地 III 中大径级树木的数量最 少 树木径级的差异直接影响着生物量的大小。

由于不同样地的生物量差别很大，仅仅依靠单 个 $1 \mathrm{hm}^{2}$ 样地来推断某一类型森林的生物量得到的 信息可靠性较低(Chave et al ，2003)。而在本研究 中 就不同地点的 3 块 $1 \mathrm{hm}^{2}$ 样地进行了分析, 且每 一块样地的面积要大于先前所进行的研究, 同时对 部分附生植物的生物量和粗死木质残体储量进行了 测定, 研究结果较好的代表了西双版纳热带季节雨 林生物量的平均水平。

\section{2 生物量预测方程的选择}

森林生物量的获得可以通过直接和间接两种途 径: 前者是将一定面积内的树木皆伐以获取其生物 量;而在热带森林的生物量测定中经常使用间接的 方法，即通过一定数量的样木建立回归模型来推算 森林群落的生物量 (Segura \& Kanninen ,2005)。而在 森林生物量模型中经常使用的参数包括 :胸径 $(D)$ 、 高度 $(H)$ 、密度 $(S)$ 。常见的预测模型包括以胸径为 单变量的模型、以胸径和树高为变量的模型以及以 胸径、高度、密度为变量的模型。但在森林群落调查 中, 各种参数获得的准确性并不一致 :胸径在绝大多 数的调查中可以较准确的获得, 而高度通常会被测 量, 但其测量均存在着较大的误差 (Brown et al. , 1989 ;Chave et al. 2001)。而生物量与胸径之间存 在着很好的相关关系, 因此在热带森林的生物量预 测中以胸径为单变量的模型被广泛运用 (Chave $e t$ 
al . 2001 ;Keller et al . 2001;Overman et al . 1994 ;Segura \& Kanninen,2005)。故在本研究中也采用以胸 径为单变量的生物量回归模型。不仅样木数量较 多, 涵盖径级范围较广，且各器官及总生物量预测方 程的相关性系数均达到极显著水平，所建立的模型 有效地预测了西双版纳热带季节雨林中树木各组分 的生物量。

\section{3 森林群落中小径级树木、大树和巨树对生物量 的贡献}

热带森林中的乔木个体具有不同年龄和径级， 从新生小苗到几百年的参天大树。虽然小径级的树 木个体与大径级个体相比, 其生物量和材积较小, 但 是较小的径级级别却包含了相对较多的个体, 因此 小径级级别同样是立地生物量的重要组成部分 (Gillespie et al.,1992)。在本研究中, 胸径 $D<10$ $\mathrm{cm}$ 的植株密度平均为 1698 株 $\mathrm{hm}^{-2}$ (表 4) , 占乔木 总株数的 $80 \%$; 其生物量仅占乔木层生物量的 $2.69 \%$ 。在生物量较大的样地 II 中, 大径级的树木 相对较多, 使得小径级树木的生物量比例较低, 仅占 $1.97 \%$;而在生物量较低的样地 I 和 III 中，小径级 树木所占的比例相对较高 $(2.86 \%$ 和 $3.58 \%)$ 。出 于不同的研究目的, 在进行生物量研究时, 不同的学 者采用的乔木最小胸径不尽相同 $(1 \sim 30 \mathrm{~cm})$ 。但是 森林生产力及碳储量与大、小径级的树木均有关系， 应将小径级树木的生物量包含于森林生物量研究之 中。

在森林群落中, 随植株胸径的增大, 个体数量多 会呈现下降的趋势。但就生物量方面而言, 大树 $(D>70 \mathrm{~cm})$ 和巨树 $(D \geqslant 200 \mathrm{~cm})$ 的贡献则是与其在 样地中的个体数量不成比例的。Clark 和 Clark (2000) 对哥斯达黎加的热带雨林生物量的研究表 明, 大树对乔木层生物量的贡献为 $14 \% \sim 30 \%$; 在 巴拿马，其比例约为 1/3(Chave et al .,2003)。但在 本研究中, 大树的生物量所占比例高达 $43.67 \% \pm$ $12.67 \%$, 远高于哥斯达黎加的热带雨林中大树的贡 献。在巴拿马 $50 \mathrm{hm}^{2}$ 的样地中大树的密度平均为 10 株 $\mathrm{hm}^{-2}$ (Chave et al. 2003) , 而在本研究中 ,3块 样地中分别存在大树 17、19 和 9 株, 平均为 15 株, 为巴拿马雨林的 1.5 倍。其中 样地 III 总生物量相 对较低的主要原因就在于大树较少, 其数量仅为其 它样地的一半。在本研究的样地 II 中, 出现 1 株巨 树 $(D=207 \mathrm{~cm})$, 其生物量占乔木层总生物量的 $16.65 \%$ 。由于巨树的出现, 同时样地 II 中大树的数 量多于其它两块样地, 使得其乔木层总生物量为无
巨树出现的样地 I 的 1.5 倍和样地 III 的 1.6 倍。 同样在巴西的热带雨林中,巨树的植株密度为小于 1 株 $\mathrm{hm}^{-2}$, 但其生物量占乔木层的 $0 \sim 42 \%$, 平均 为 $14 \%$ (Cummings et al. 2002)。鉴于大树和巨树 对生物量的巨大贡献，提高大径级树木生物量的估 测精度则显得尤为重要, 这也是以后进行生物量研 究中尤其是样地和样木选择时应该注意的问题。

\section{参 考 文 献}

Araujo TM, Higuchi N, Carvalho JA (1999) . Comparison of formulae for biomass content determination in a tropical rain forest site in the state of Para, Brazil. Forest Ecology and Management, $117,43-52$.

Brown FI, Martinelli LA, Thomas WW, Moreira MZ, Ferreira CC, Victoria RA (1995). Uncertainty in the biomass of Amazonian forests: an example from Rondonia, Brazil. Forest Ecology and Management, 75, 175 - 189 .

Brown S (1997) . Estimating biomass and biomass change of tropical forests: a primer. In: Brown S ed. UN-FAO Forestry Paper No. 134. FAO, Rome, $1-31$.

Brown S, Gillespie A, Lugo AE (1989). Biomass estimation methods for tropical forests with applications to forest inventory data. Forest Science, 35, $881-902$.

Brown S, Lugo AE(1982). The storage and production of organic matter in tropical forests and their role in the global carbon cycle. Biotropica, 14, $161-187$.

Cao M, Zhang JH, Feng ZL, Deng JW, Deng XB (1996). Tree species composition of a seasonal rain forest in Xishuangbanna, Southwest China. Tropical Ecology, 37, 183-192.

Chave J, Condit R, Lao S, Caspersen JP, Foster RB, Hubbell SP (2003). Spatial and temporal variation of biomass in a tropical forest: results from a large census plot in Panama. Journal of Ecology, 91, 240-252.

Chave J, Riera B, Dubois MA (2001) . Estimation of biomass in a neotropical forest of French Guiana: spatial and temporal variability. Journal of Tropical Ecology, 17, $79-96$.

Clark DB, Clark DA (2000). Landscape-scale variation in forest structure and biomass in a tropical rain forest. Forest Ecology and Management, 137, $185-198$.

Condit R, Hubbell SP, Foster RB (1995). Mortality rates of 205 neotropical tree and shrub species and the impact of a severe drought. Ecological Monographs, 65, 119-139.

Cummings DL, Kauffman JB, Perry DA, Hughes RF (2002). Aboveground biomass and structure of rainforests in the Southwestern Brazilian Amazon. Forest Ecology and Management, $163,293-307$.

Dang CL(党承林), Wu ZL(吴兆录), Zhang Q(张强) (1997). A study on biomass of the ravine tropical rain forest in Xishuangbanna. Acta Botanica Yunnanica (云南植物研究), (Suppl. IX), 123 - 128. (in Chinese with English abstract)

Dewalt SJ, Chave J (2004). Structure and biomass of four lowland neotropical forests. Biotropica, 36, 7-19.

Dixon RK, Brown S, Houghton RA, Solomon AM, Trexler MC, Wisniewski J (1994) . Carbon pools and flux of global forest ecosystems. Science, 263, 185-190. 
Feng ZL(冯志立), Zheng Z(郑征), Zhang JH(张建侯), Cao M (曹敏), Sha LQ (沙丽清), Deng JW (邓继武) (1998). Biomass and its allocation of a tropical wet seasonal rain forest in Xishuangbanna. Acta Phytoecologica Sinica (植物生态学报), 22, 481 - 488. (in Chinese with English abstract)

Gillespie A, Brown S, Lugo AE (1992). Tropical forest biomass estimation from truncated stand tables. Forest Ecology and Management, 48, 69-87.

Gurney KR, Law RM, Denning AS, Rayner PJ, Baker D, Bousquet $\mathrm{P}$ (2002). Towards robust regional estimates of $\mathrm{CO}_{2}$ sources and sinks using atmospheric transport models. Nature, 415, $626-630$.

Huang Q(黄全), Li YD(李意德), Lai JZ(赖巨章), Peng GQ (彭国金) (1991). Study on biomass of tropical mountain rain forest in Limushan, Hainan Island. Acta Phytoecologica et Geobotanica Sinica (植物生态学与地植物学学报), 15, 197 206. (in Chinese with English abstract)

Keller M, Palace M, Hurtt G (2001). Biomass estimation in the Tapajos National forest, Brazil: examination of sampling and allometric uncertainties. Forest Ecology and Management, 154 $371-382$.

Körner C (1998) . Tropical forests in a $\mathrm{CO}_{2}$-rich world. Climatic Change, 39, $297-315$.

Laurance WF, Fearnside PM, Laurance SG, Delamonica P, Lovejoy TE, Rankin-de-merona JM, Chambers JQ, Gascon C (1999). Relationship between soils and Amazon forest biomass: a landscape-scale study. Forest Ecology and Management, 118, $127-138$

Li LH (李凌浩), Xing XR(邢雪荣), Huang DM(黄大明), Liu CD(刘初钿), He JY (何建源) (1996). Storage and dynamics of coarse woody debris in Castanopsis eyeri forest of Wuyi Mountain, with some consideration for its ecological effects. Acta Phytoecologica Sinica (植物生态学报), 20,132-143. (in Chinese with English abstract)

Li YD(李意德), Wu ZM(吴仲民), Zeng QB(曾庆波), Zhou $\mathrm{GY}$ (周光益), Chen BF (陈步峰), Fang JY (方精云) (1996). Carbon pool and carbon dioxide dynamics of tropical mountain rain forest ecosystem at Jianfengling, Hainan Island. Acta Ecologica Sinica (生态学报), 18, 371 - 378. (in Chinese with English abstract)

Malhi Y, Baldocchi DD, Jarvis PG (1999). The carbon balance of tropical, temperate and boreal forests. Plant, Cell and Environment, 22, $715-740$.

Malhi Y, Nobre AD, Grace J, Kruijt B, Pereira MGP, Culf A, Scott S (1998) . Carbon dioxide transfer over a Central Amazonian rain forest. Journal of Geophysical Research-Atmospheres, $103,31593-31672$.
Overman JPM, Witte HJL, Saldarriaga JG (1994) . Evaluation of regression models for above-ground biomass determination in Amazon rainforest. Journal of Tropical Ecology, 10, 207 - 218 .

Phillips OL, Gentry AH (1994). Increasing turnover through time in tropical forests. Science, 263, $954-958$.

Schimel DS (1995). Terrestrial ecosystems and the carbon cycle. Global Change Biology, 1, 77 - 91 .

Segura M, Kanninen M (2005). Allometric models for tree volume and total aboveground biomass in a tropical humid forest in Costa Rica. Biotropica, 37, $2-8$.

Tang JW(唐建维), Zhang JH(张建侯), Song QS(宋启示), Huang ZY (黄自云), Li ZN (李自能), Wang LF(王利繁), Zeng R(曾荣) (2003). Biomass and net primary productivity of artificial tropical rainforest in Xishuangbanna. Chinese Journal of Applied Ecology (应用生态学报), 14, 1-6. (in Chinese with English abstract)

Wen DZ(温达志), Wei P(魏平), Zhang QM(张倩媚), Kong GH(孔国辉) (1999). Studies on biomass of three lower subtropical evergreen broad-leaved forests in a MAB reserve of South China. Acta Phytoecologica Sinica (植物生态学报), 23 (Suppl. ), $11-21$. (in Chinese with English abstract)

Wu BX(吴邦兴) (1992). Studies on the vertical structure of seasonal rain-forest in Xishuangbanna of Yunnan. Acta Botanica Sinica (植物学报), 33, 232 - 239. (in Chinese with English abstract)

Zheng Z(郑征), Feng ZL(冯志立), Cao M(曹敏), Liu HM(刘 宏茂), Liu LH(刘伦辉) (2000). Biomass and net primary production of primary tropical wet seasonal rainforest in Xishuangbanna. Acta Phytoecologica Sinica (植物生态学报), 24, 197 - 203. (in Chinese with English abstract)

Zheng Z(郑征), Liu HM(刘宏茂), Liu LH(刘伦辉), Cao M (曹敏), Feng ZL(冯志立) (1999). A study on biomass of the primary tropical rain forest in Xishuangbanna. Guihaia (广西植 物 ), 19, 309-314. (in Chinese with English abstract)

Zheng Z(郑征), Feng ZL(冯志立), Liu HM(刘宏茂), Meng Y (孟盈), Gan JM(甘建民) (2001). Influence of planting Amomum villosum in tropical wet seasonal rainforest on biomass of the rainforest in Xishuangbanna. Journal of Mountain Science (山地 学报), 19, 237 - 242. (in Chinese with English abstract)

Zhu H(朱华), Cai L(蔡琳) (2005). Biogeography of the tropical rain forest of Yunnan and some implications to geological history. Advances in Earth Science (地球科学进展), 20 (Suppl. ), 1 57. (in Chinese with English abstract)

Zhu H(朱华), Wang H(王洪), Li BG(李保贵), Xu ZF(许再 富 ) ( 1998 ). Research on tropical seasonal rainforest of Xishuangbanna, South Yunnan. Guihaia (广西植物), 18, 372 - 384. (in Chinese with English abstract) 